
\title{
$\begin{array}{ll}\text { Research Square } & \text { They should not be considered conclusive, used to inform clinical practice, } \\ \text { or referenced by the media as validated information. }\end{array}$ \\ Can the Olive Genome Be a Miracle for Human DNA?
}

\section{Muhammet ŞENKAL}

istanbulmedeniyet university

Ibrahim Akalin ( $\square$ ibrahimakalin@yahoo.com )

Maltepe University Faculty of Medicine https://orcid.org/0000-0002-7487-4603

\section{Article}

Keywords: Olive, genome, CALM1, CALM3, BRAF, SDHA, BRMS1L

Posted Date: May 26th, 2021

DOI: https://doi.org/10.21203/rs.3.rs-557479/v1

License: (c) (1) This work is licensed under a Creative Commons Attribution 4.0 International License. Read Full License 


\title{
Can the Olive Genome Be a Miracle for Human DNA?
}

\author{
AUTHORS Akalın $\dot{I}^{1}$, Şenkal M. ${ }^{2}$ \\ CORRESPONDING AUTHOR Akalın $\dot{I}^{2}$ \\ ${ }^{1}$ İstanbul Medeniyet University, Department of Medical Genetics, Istanbul \\ ${ }^{2}$ İstanbul Medeniyet University, Faculty of Medicine, 4rd year student, Istanbul
}

\section{ABSTRACT}

In this project, it is aimed to compare the olive genome, one of the fruits of the Mediterranean region, to the human genome. We started plant-human genomic studies with olive on the hypothesis that whether we could consume the benefits of carbohydrates, proteins, fats, as well as genomic bioavailability. Many studies from past to present have shown positive effects of olives on cardiovascular diseases and some cancer pathways. In terms of both scientific and religious resources, olive is an important plant in many areas. In our project, we compared the olive genome with the human genome in Pubmed database. We detected pathological or non-pathological variations of the matching regions in the human genome. We investigated whether these variations were found in the olive genome as wild type and whether there were regions suitable for cutting in terms of restriction enzymes. In the data obtained, the presence of cardiovascular and cancer-related genes of the matching regions suggests a possible bioavailability. In the ongoing projects, it is aimed to compare the genomes of plants other than olive with the human genome.

Keywords Olive, genome, CALM1, CALM3, BRAF, SDHA, BRMS1L

\section{INTRODUCTION}

Olive, which is one of the fruits of the Mediterranean region, has managed to become an indispensable part of the tables from past to present. Both the mention of its name in religious books and its examination in terms of cardiovascular diseases in many scientific articles emphasize the importance of olive many times. It is reported that olive and olive oil consumption is associated with a decrease in the incidence and mortality of cardiovascular 
diseases such as heart failure, atrial fibrillation and atherosclerosis. [1] Olive oil diet has antioxidant properties [2], anti-inflammatory [3] and anti-carcinogenic properties [4]. Based on the verse of the Qur'an, figs and olives mentioned in Surah Tin, it is aimed to examine the possible effects of olives sworn on in the Qur'an from a genetic perspective. Is there any genomic bioavailability of plants besides carbohydrate, fat, protein? We know that our microbiata has restriction enzymes that can cut the genome of the digested food from many different regions. So, could the genome of a food be cut into our enteric flora and presented to us? Starting from here, we compared the human genome with the olive genome in our project. We detected pathological or non-pathological variations of the matching regions in the human genome. We investigated whether these variations were found in the olive genome.

\section{METRIALS AND METDHODS}

- The olive genome sequence in the Pubmed genome database was mapped to the human genome on the NucleotidBlast site.

- Variations of the matching regions were searched in databases such as Pubmed, PolyPhen-2, Exac.browser to find deletion sites and SNPs causing pathogenicity.

- In addition, the restriction enzymes found in the olive genome matching regions were determined using the NEB site.

\section{RESULTS}

- When the olive genome is examined from Pubmed Genome, it is known to have 23 chromosomes. [8]

- In the comparison of olive and human genomes, we detected 73-100 percent matches in 67 genes. (Table 2, 3)

- Matching genes are found in cancer (BRAF, BRMS1L, SDHA) and calmodulin (CALM1, CALM3) related genes. 


\section{CALM1 GENE FINDINGS}

- The CALM1 gene encodes a member of the EF-hand calcium binding protein family. [9]

- $84 \%(125 / 149)$ matches were found between the olive genome and $149 \mathrm{bp}$ in the third exon

of the CALM1 gene (Figure 1).

PREDICTED: Olea europaea var. sylvestris calmodulin-7 (LOC111405877), transcript variant X2, mRNA Sequence ID: XM 023034963.1 Length: 809 Number of Matches: 1

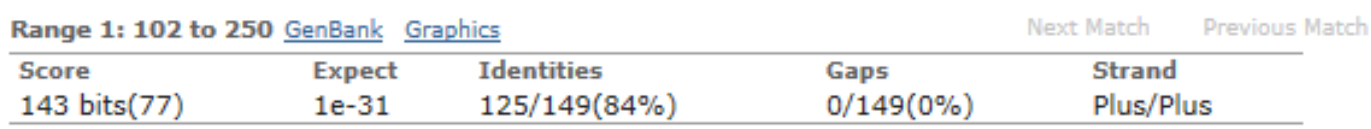

Query 4273 TCAGAATTCAAGGAAGCCTTCTCCCTATTTGATAAAGATGGCGATGGCACCATCACAACA 4332

Sbjct $102 \quad$ TCCGAATTCAAGGAAGCCTTCTCCCTATTTGACAAGGACGGCGATGGTTGCATCACTACT 161

Query 4333 AAGGAACTTGGAACTGTCATGAGGTCACTGGGTCAGAACCCAACAGAAGCTGAATTGCAG 4392

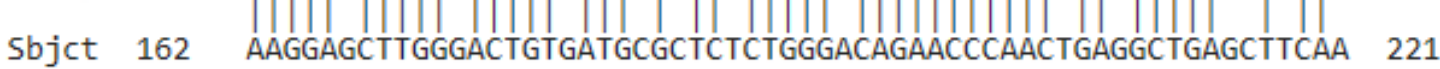

Query 4393 GATATGATCAATGAAGTGGATGCTGATGG 4421

sbjet 222 GATATGATCAATGAGGTTGATGCTGATGG 250

Figure 1 Matching region between olive genome and CALM1 gene. 125/149 bp (84\%) matches between the olive genome and the CALM1 gene are shown.

- There are 19 SNPs in the pubmed database in our region that matches the CALM1 gene. (Figure 2)

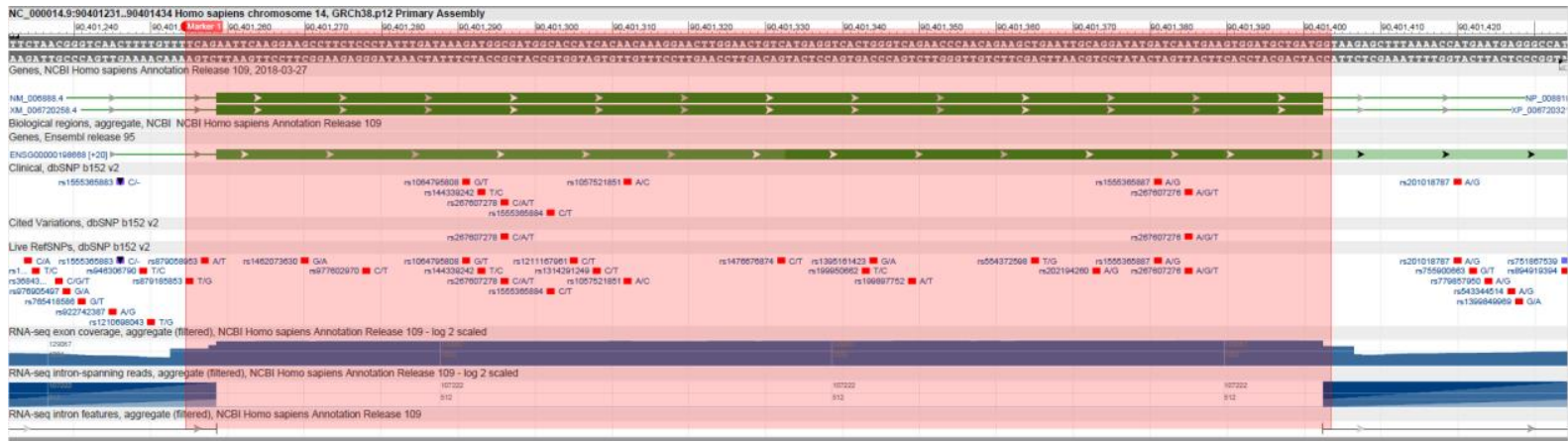

Figure 2 SNPS reported in the Pubmed database in the region matching the CALM1 gene. The Marker 1 region indicated with red indicates the region that matches the CALM1 gene. This region is between nucleotides 90,401,255-90,401,403 (149bc) in human genome 14 Chromosome, GRCh38p.12. Direction of arrows in the green line The olive genome shows the direction of the 5'-3 Zeytin DNA sequence. The red regions indicated by the Rs numbers refer to the SNPs reported in the Pubmed database. The data obtained were investigated on 2018-03-27.

- In this range, rs26707276 SNP (chr14: 90401385 (GRCh38.p12) A / G / T) is clinically important and pathogenic / potentially pathogenic. [5] [6] [10]

- $\quad$ SNP pathology was also found in the MutationTarget database. (Table 1) 
Table 1 shows the pathogenetic SNP in the MutationTarget database of rs26707276 SNP, which is located at the matching region between the olive genome and the CALM1 gene. [11th]

\begin{tabular}{|c|c|c|c|c|c|c|c|c|c|c|}
\hline SNP & ORGANISM_BUILD & CHR & COORDINATE & $\begin{array}{l}\text { REF } \\
\text { ALLELE } \\
\end{array}$ & $\begin{array}{l}\text { ALT } \\
\text { ALLELE } \\
\end{array}$ & $\begin{array}{l}\text { AMINO ACID } \\
\text { CHANGE }\end{array}$ & GENE NAME & REGION & $\begin{array}{l}\text { NO OF } \\
\text { SEQS AT } \\
\text { POSITION }\end{array}$ & $\begin{array}{l}\text { SIFT } \\
\text { PREDICTION }\end{array}$ \\
\hline rs267607276 & Homo_sapiens/GRCh37.74 & 14 & 90867729 & A & $\mathrm{T}$ & N54I & CALM1 & CDS & 387 & DELETERIOUS \\
\hline rs267607276 & Homo_sapiens/GRCh37.74 & 14 & 90867729 & $\mathrm{~A}$ & $\mathrm{~T}$ & N55I & CALM1 & CDS & 394 & DELETERIOUS \\
\hline rs267607276 & Homo_sapiens/GRCh37.74 & 14 & 90867729 & A & $\mathrm{T}$ & N18I & CALM1 & CDS & 379 & DELETERIOUS \\
\hline rs267607276 & Homo_sapiens/GRCh37.74 & 14 & 90867729 & A & $\mathrm{T}$ & N18I & CALM1 & CDS & 379 & DELETERIOUS \\
\hline
\end{tabular}

- The non-pathological wild type form of the region found in rs267607276 SNP is found in the olive genome. (Figure 3)

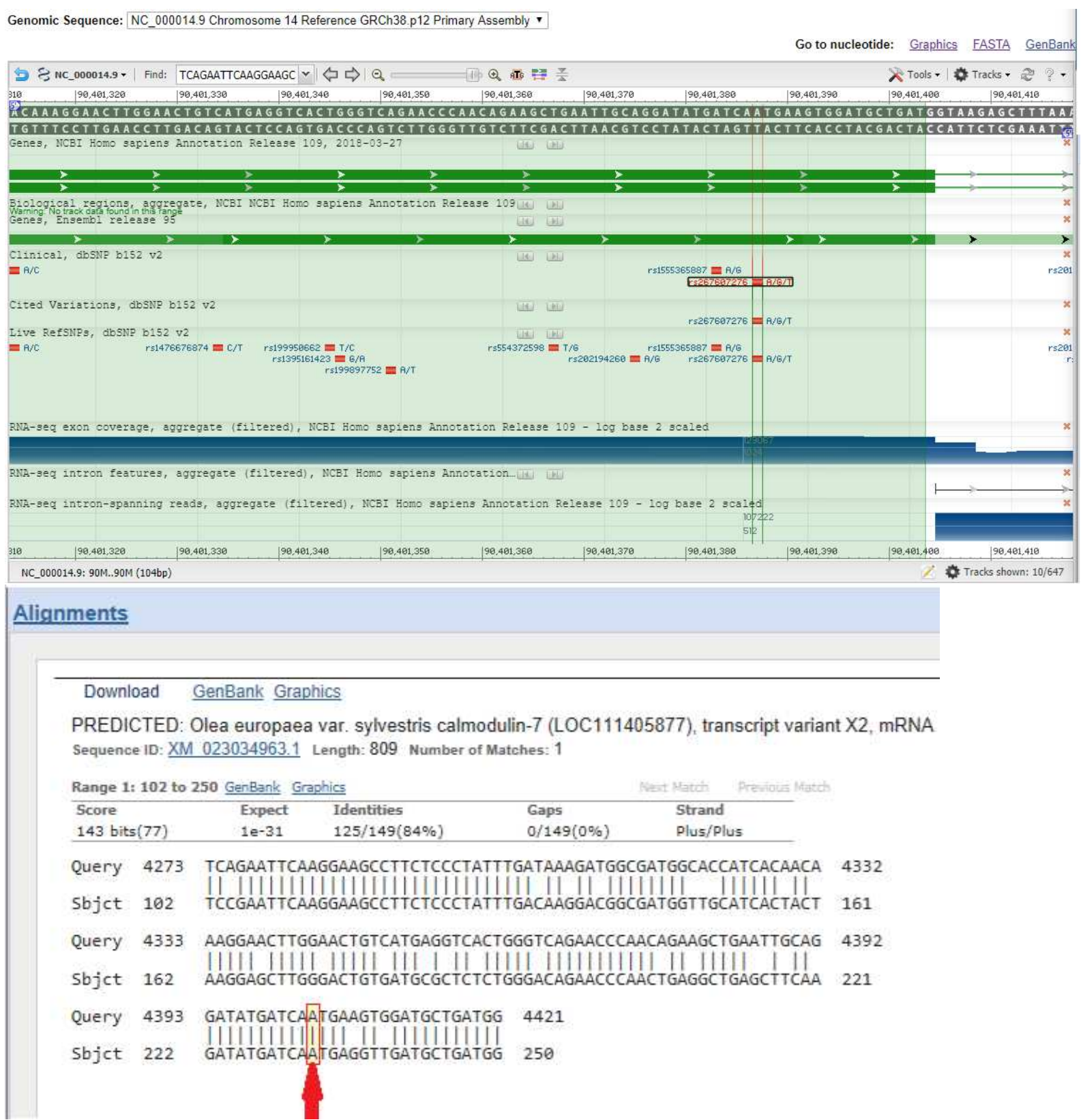


Figure 3. Wild type of SNP (Red Arrow), a pathogenic variant of the human genome, rs267607276, is shown in the olive genome.

- There are many candidate regions for restriction enzymes in the 149 bp region we found a match. (figure

4)

\begin{tabular}{|c|c|c|}
\hline \multicolumn{3}{|c|}{ Linear Sequence: unnamed sequence } \\
\hline $\begin{array}{l}\text { Display: - NEB single cutter restriction enzymes } \\
\text { - Main non-overlapping, min. } 100 \text { aa ORFs } \\
\text { GC }=45 \%, A T=55 \%\end{array}$ & \begin{tabular}{l|l} 
I I blunt end cut \\
| I 5 ' extension \\
I 3 ' extension \\
I cuts 1 strand
\end{tabular} & $\begin{array}{l}\text { Available from NEB } \\
\text { Has other supplier } \\
\text { Not commercially available } \\
*: \text { cleavage affected by CpG methylation } \\
\text { \#: cleavage affected by other methylation } \\
\text { (enz. name): ambiguous site }\end{array}$ \\
\hline
\end{tabular}

\begin{tabular}{llllll}
\hline EcoRI \\
Apol
\end{tabular}

Figure 4. Restriction enzymes in the NEB database of the region matching the CALM1 gene. 
- There is a possibility that the matching region by the restriction enzymes may be appropriately removed (Figure 5)

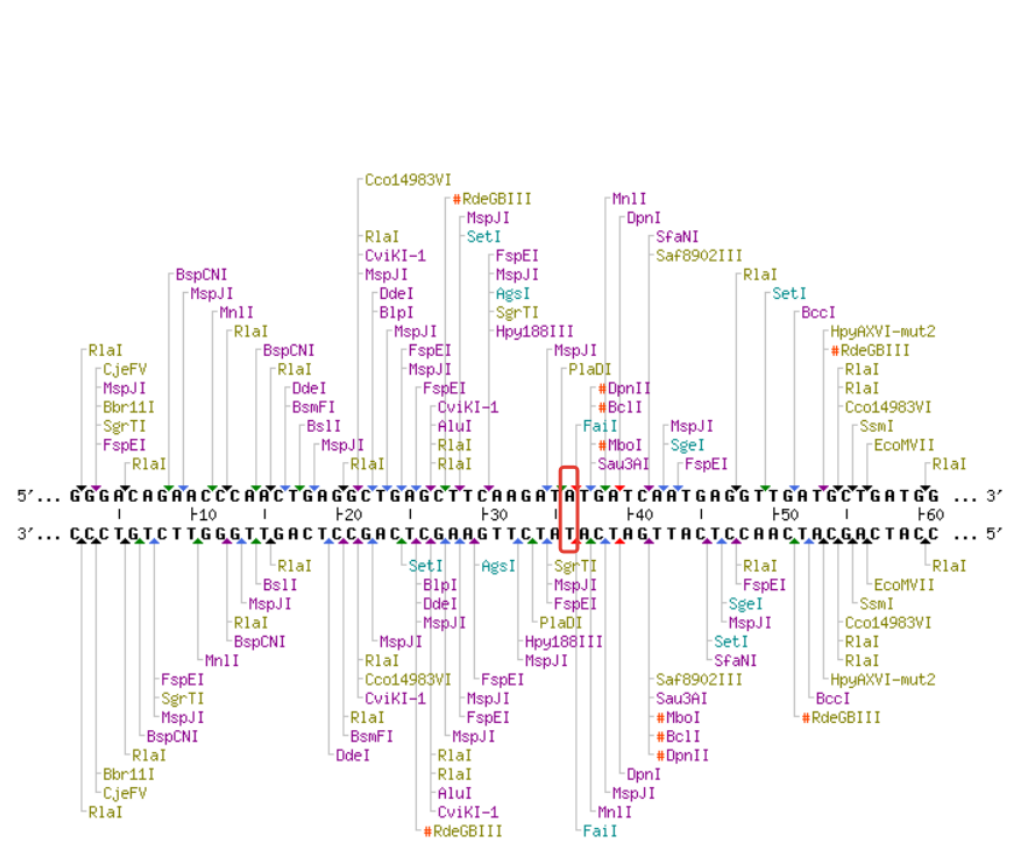

Figure 5. Restriction enzyme cleavage sites located in the proximal positions of the pathological rs267607276 SNP (circled in red) in the region matching the CALM1 gene.

\section{BRAF GENE FINDINGS}

- $\quad$ BRAF plays a role in regulating the MAP kinase / ERK signaling pathway, which affects cell division, differentiation and secretion.

- $\quad 31 / 32(97 \%)$ matches were found between olive genome and 32 bp of BRAF gene. (Figure 6)

Homo sapiens B-Raf proto-oncogene, serine/threonine kinase (BRAF), transcript variant 1, mRNA Sequence ID: NM 004333.5 Length: 4560 Number of Matches: 1

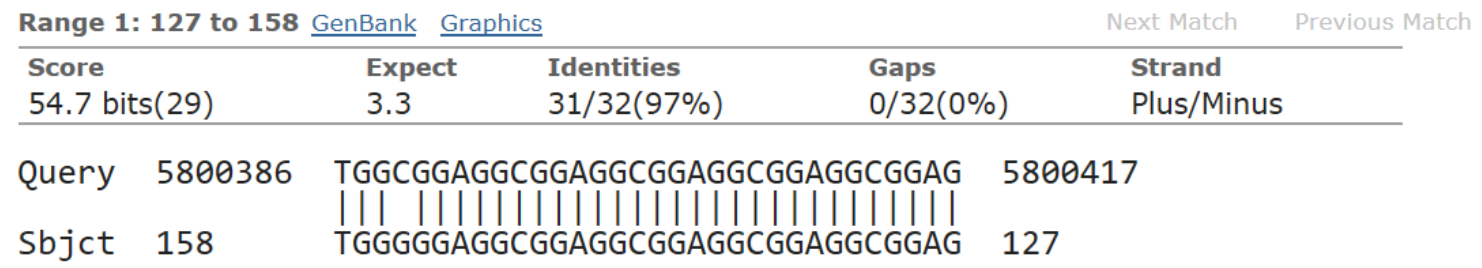

Figure 6. Matching region between olive genome and BRAF gene. 31/32 bp (97\%) matches between olive genome and BRAF gene are shown.

- $\quad$ There are 9 SNPs and 9 deletions in the pubmed database in our region that matches the BRAF gene. (figure 7) 


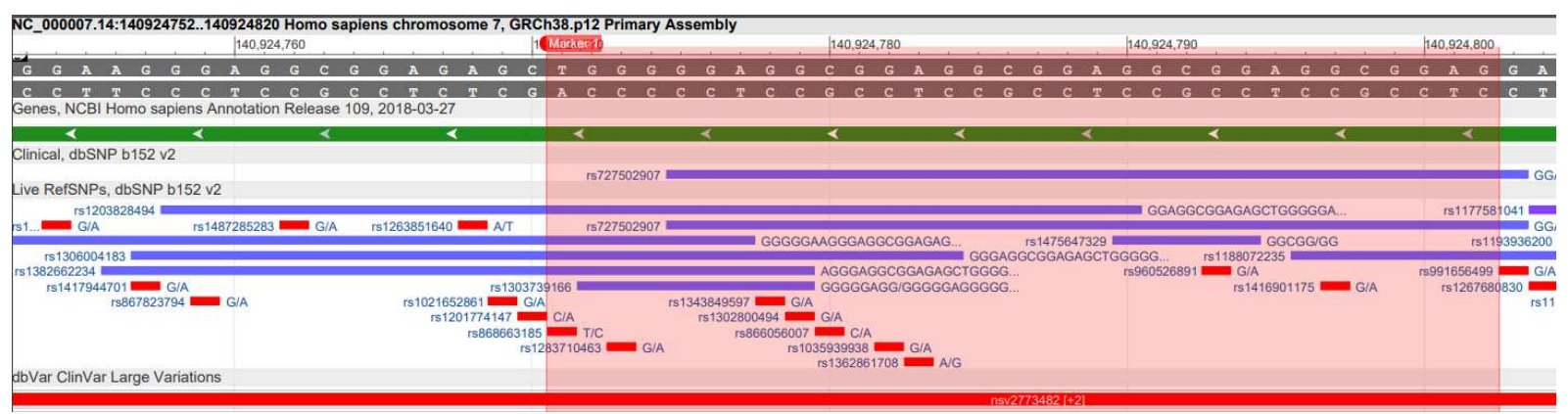

Figure 7. SNPs reported in the Pubmed database in the region matching the BRAF gene. The Marker 1 region indicated by the red indicates the region that matches the BRAF gene. This region is among the nucleotides 140,924,771 -140,924,802 (32b) in the Human genome 7. Chromosome, GRCh38p.12. Direction of arrows in the green line The olive genome shows the direction of the 5'-3 Zeytin DNA sequence. The red regions indicated by the Rs numbers indicate the SNPs reported in the Pubmed database, and the blue lines of longer lines indicate the deletion sites reported. The data obtained were investigated on 2018-03-27.

- Wild type form of all SNP and deletions except rs267607276 SNP is found in olive genome.

- In Figure 7, there are many candidate regions for restriction enzymes in the 32b region where we found a match with the BRAF gene. (Figure 8.)

\begin{tabular}{|c|c|c|}
\hline \multicolumn{3}{|c|}{ Linear Sequence: unnamed sequence } \\
\hline $\begin{array}{l}\text { Display: - All commercial restriction enzymes } \\
\mathrm{GC}=81 \%, \mathrm{AT}=19 \%\end{array}$ & $\begin{array}{l}\text { I blunt end cut } \\
\text { | } 5 \text { ' extension } \\
\text { | } 3 \text { ' extension } \\
\text { | cuts } 1 \text { strand }\end{array}$ & $\begin{array}{l}\text { Available from NEB } \\
\text { Has other supplier } \\
\text { Not commercially available } \\
\text { *: cleavage affected by CpG methylation } \\
\text { \#: cleavage affected by other methylation } \\
\text { (enz. name): ambiguous site }\end{array}$ \\
\hline
\end{tabular}

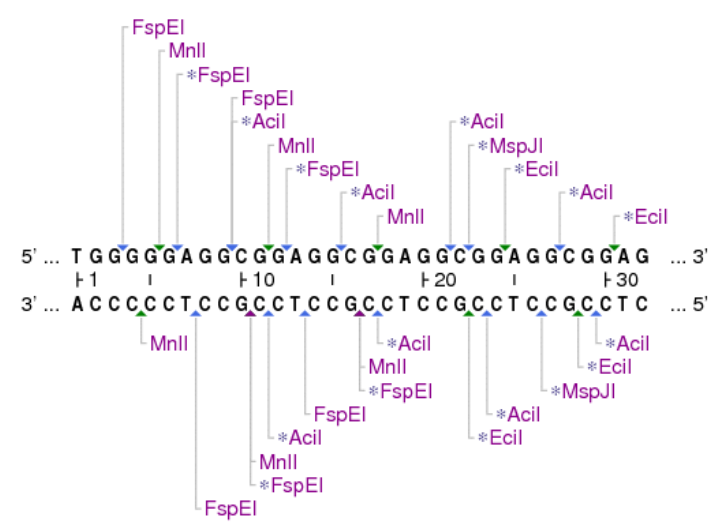

Figure 8. Restriction enzymes in the NEB database of the region matching the BRAF gene.

\section{SDHA GENE FINDINGS}

- $84 \%(77 / 92)$ matches were found between the olive genome and 92 bp in the 5th exon of the SDHA gene (Figure 9) 
Homo sapiens succinate dehydrogenase complex flavoprotein subunit A (SDHA), transcript variant 3, mRNA Sequence ID: NM_001330758.1 Length: 2547 Number of Matches: 2

\begin{tabular}{lcllll}
\multicolumn{2}{l}{ Range 1: 587 to 678 GenBank } & \multicolumn{2}{l}{ Graphics } & Next Match & Previous Match \\
\hline Score & Expect & Identities & Gaps & Strand \\
87.9 bits(47) & $4 e-10$ & $77 / 92(84 \%)$ & $0 / 92(0 \%)$ & Plus/Minus \\
\hline
\end{tabular}

\begin{tabular}{|c|c|c|c|c|}
\hline Query & 6554306 & TTTCCAAAGTTTAGGCTTTGACCACCAAATGCA & CGCTGATAAATCTTCCCATCTTCGGTC & 6554365 \\
\hline Sbjct & 678 & TTTCCAAACTTGAGGCTCTGTCCACCAAATGCA & CGCTGATAAATCTTCCCATCTTCAGTT & 619 \\
\hline Query & 6554366 & ATTTTCAAGCTC & 6554397 & \\
\hline Sbjet & 618 & CTGCTAAACGGCATGCCATAATTTTCTAGCTC & 587 & \\
\hline
\end{tabular}

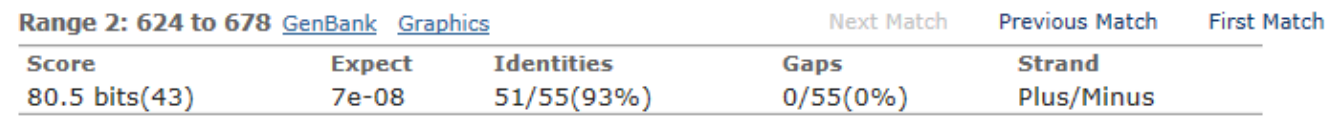

$\begin{array}{llll}\text { Query } & 6327075 & \text { TTTCCAAAGTTTAGGCTTTGACCACCAAATGCACGCTGATAAATCTTCCCATCTT } & 6327129 \\ \text { Sbjet } & 678 & \text { TTTCCAAACTTGAGGCTCTGTCCACCAATGCACGCTGATAAATCTTCCCATCTT } & 624\end{array}$

Figure 9. The matching region between the olive genome and the SDHA gene. A 77/92 bp (84\%) match between the olive genome and the SDHA gene is shown. 2 matches are shown. Second match is a 51/55 bp (93\%) region within the first match.

- $\quad$ There are 33 SNPs and 4 deletions in the pubmed database in our region matching SDHA gene. (Figure

10)

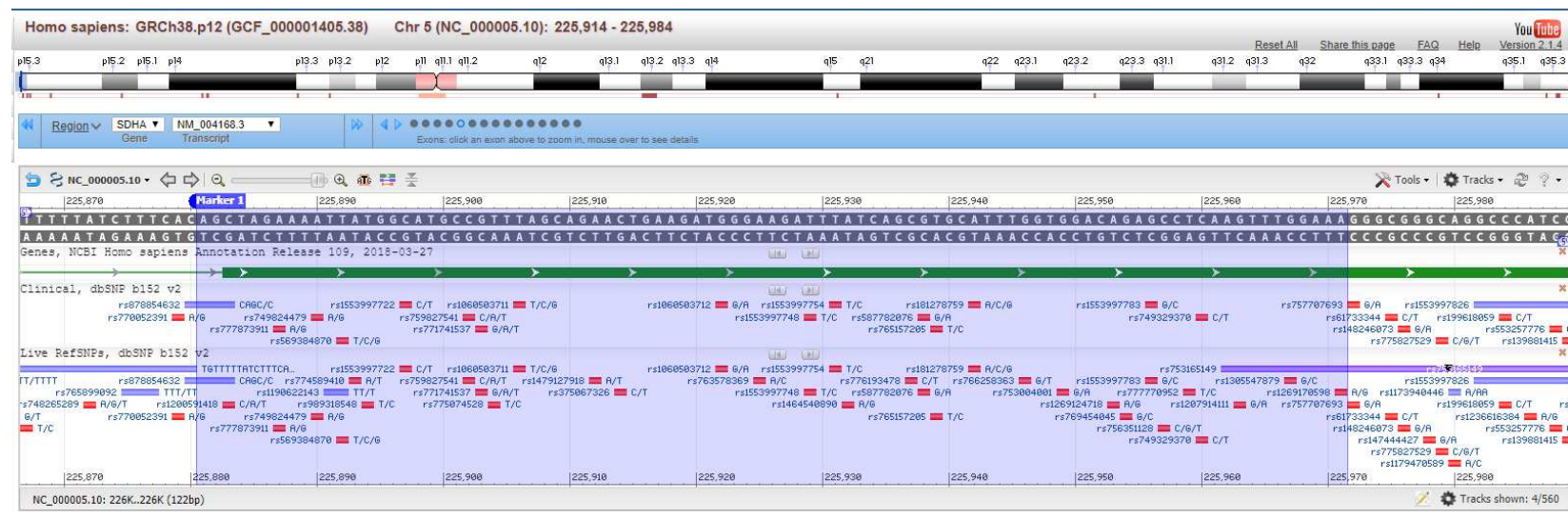

Figure 10. SNPs reported in the Pubmed database in the region matching the SDHA gene. The Marker 1 region indicated in blue indicates the region that matches the SDHA gene. This region is among the nucleotides 225,880-222,971 (92b) in the Human genome 7. Chromosome, GRCh38p.12. The direction of the arrows in the green line The olive genome shows the direction of the 3'-5 'DNA sequence. The red regions indicated by the Rs numbers indicate the SNPs reported in the Pubmed database and the purple lines with longer lines indicate the deletion areas reported. The data obtained were investigated on 2018-03-27.

- Most SNPs present are Missense Variants, leading to pathologies such as Hereditary cancerpredisposing syndrome, Mitochondrial complex II deficiency, Paragangliomas 5 and ome of their wild types are found in the olive genome. [12] [13] ( Uncertain-Significance related SNPs are rs1560987595, rs1560987595, rs749824479, rs569384870, rs1553997722, rs759827541, rs1060503711, rs1060503712, rs763578369, rs1553997748, rs1553997754, rs587782076, rs1553997783) 
- There are many candidate regions for restriction enzymes in the 92bc region where we found a match.

(Figure 11)

\section{Biolabs \\ BioLabs \\ NEBe utter}

Display: - NEB single cutter restriction enzymes

- Main non-overlapping, min. 100 aa ORFs

$\mathrm{GC}=42 \%, \mathrm{AT}=58 \%$

\section{Linear Sequence: unnamed sequence}

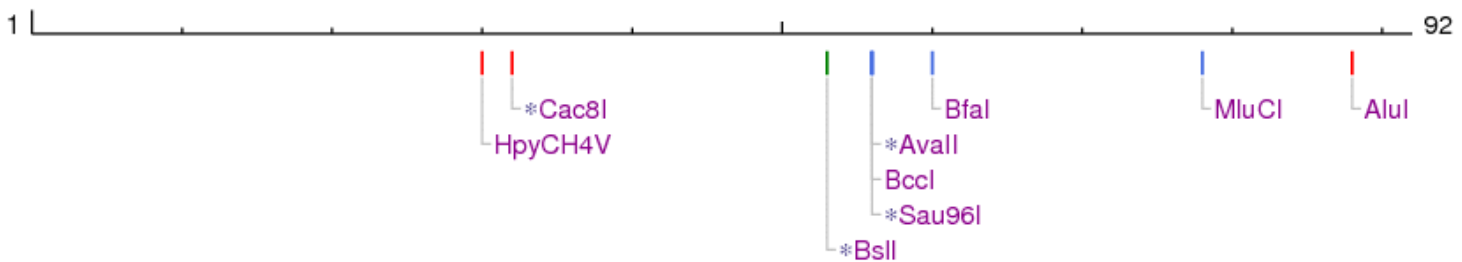

Figure 11. Restriction enzymes in the NEB database of the region matching the SDHA gene candidate regions.

\section{BRMS1L GENE FINDINGS}

- $\quad 92 \%(36 / 39)$ matches were found between the olive genome and $39 \mathrm{bp}$ in the 5 'UTR region of the BRMS1L gene. (Figure 12)

PREDICTED: Homo sapiens breast cancer metastasis-suppressor 1 like (BRMS1L), transcript variant X7, mRNA

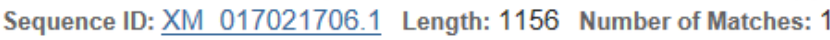

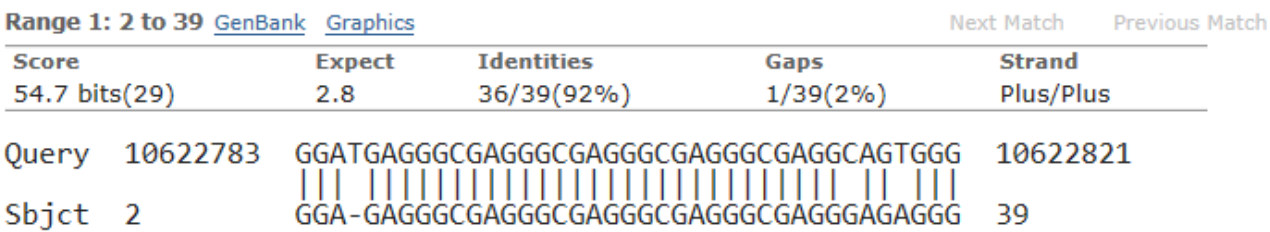

Figure 12. Matching region between olive genome and BRMS1L gene. A 36/39 bp (92\%) match between the olive genome and the BRMS1L gene is shown.

- In our region that matches the BRMS1L gene, there are 17 SNPs and 6 deletions in the pubmed database. (Figure 13) 


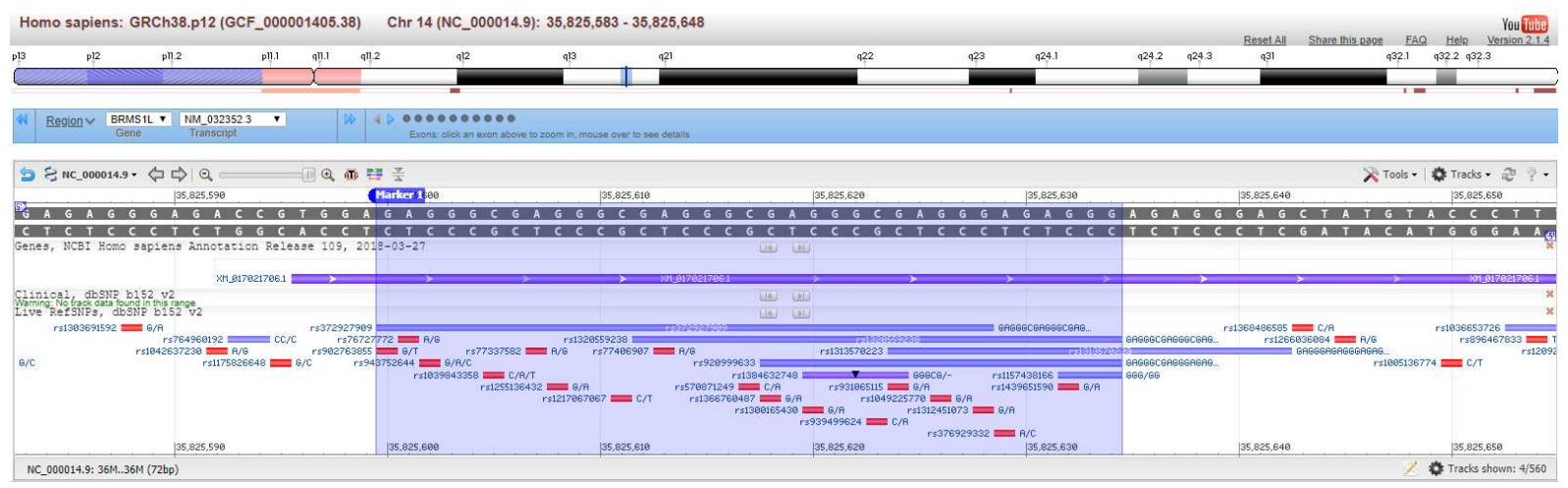

Figure 13. SNPs reported in the Pubmed database at the region matching the BRMS1L gene. The Marker 1 region indicated in blue indicates the region that matches the BRMS1L gene. This region is among the nucleotides 35,825,600 - 35,825,634 (35bc) in Human genome 14 Chromosome, GRCh38p.12. The direction of the arrows in the purple line The olive genome shows the direction of the 3'-5 'DNA sequence. The red regions indicated by the Rs numbers indicate the SNPs reported in the Pubmed database and the purple lines with longer lines indicate the deletion areas reported. The data obtained were investigated on 2018-03-27.

- The wild type of most of the SNP-containing regions is found in the olive genome.

- $\quad$ There are many candidate regions for restriction enzymes in the 39 bp region where we found a match.

(Figure 14)

\section{BioLabs \\ NEBcutter}

Display: - All commercial restriction enzymes

$\mathrm{GC}=77 \%, \mathrm{AT}=23 \%$

\section{Linear Sequence: unnamed sequence}

Cleavage code
I blunt end cut
I 5' extension
I 3' extension
I cuts 1 strand

Enzyme name code

Available from NEB Has other supplier

Not commercially available

*: cleavage affected by CpG methylation \#: cleavage affected by other methylation (enz. name): ambiguous site

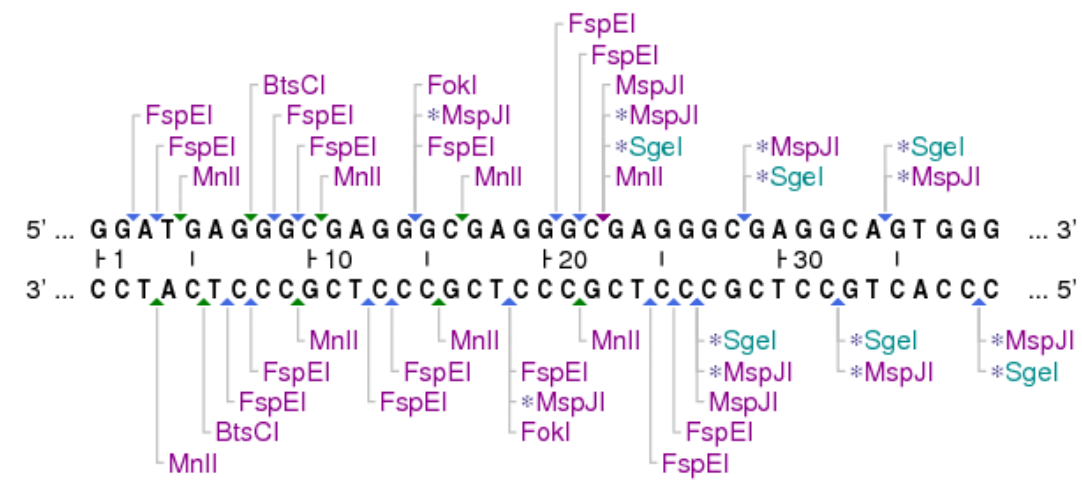

Figure 14. Restriction enzymes in the NEB database of the region matching the BRMS1L gene.

\section{CALM3 GENE FINDINGS}

- $\quad 79 \%(293 / 369)$ matches were found between the olive genome and 369 bp in 3rd, 4th, 5th and 6th exons of the CALM 3 gene. (Figure 15) 
Homo sapiens calmodulin 3 (CALM3), transcript variant 3, mRNA

Sequence ID: NM_001329922.1 Length: 2227 Number of Matches: 1

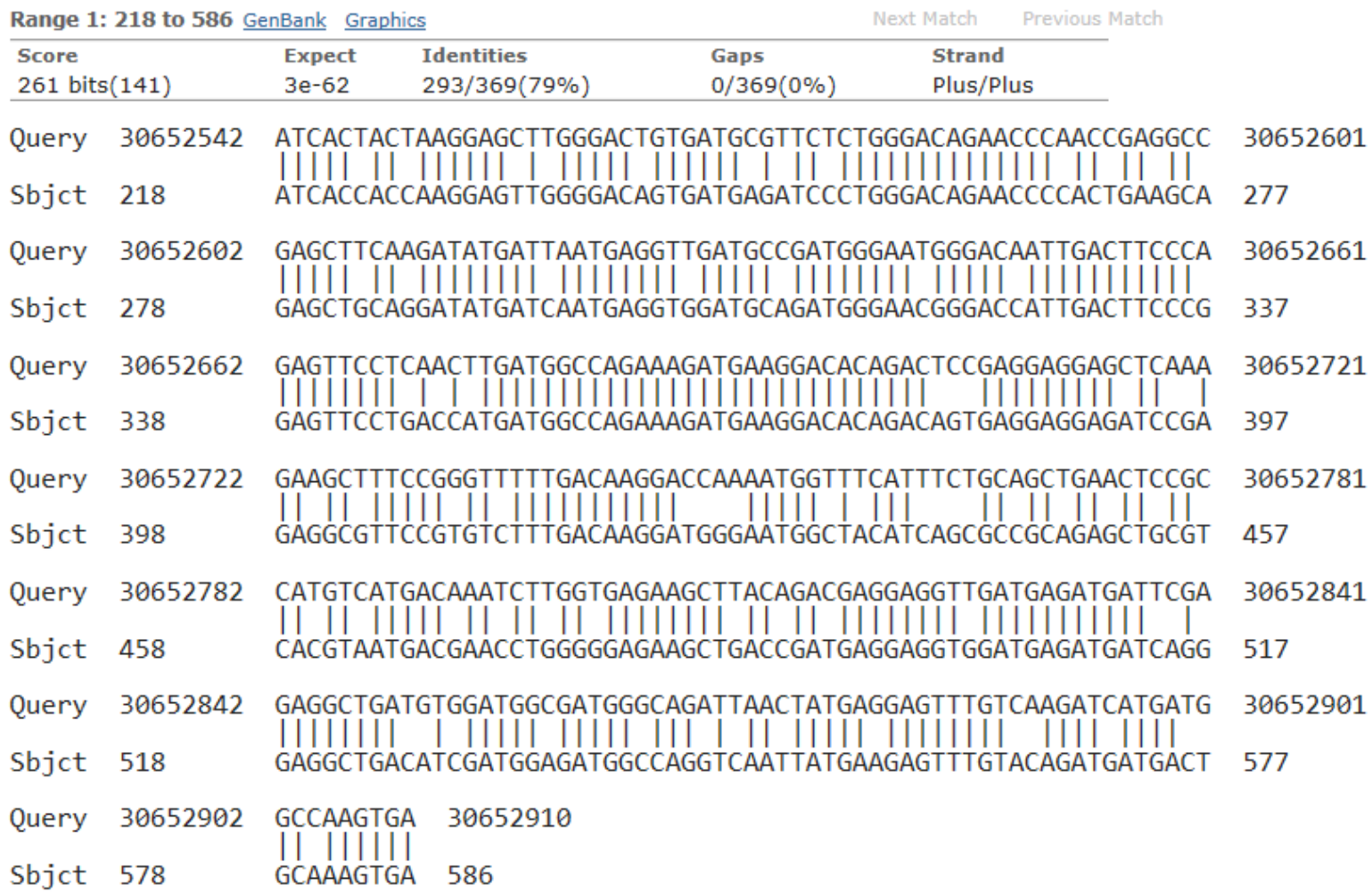

Figure 15. Mapping region between olive genome and CALM 3 gene. 293/369 bp (79\%) matches between the olive genome and the CALM3 gene are shown.

- There are 62 SNPs and 1 deletion in the pubmed database in our region that matches CALM3 gene.

(Figures 16, 17, 18, 19)

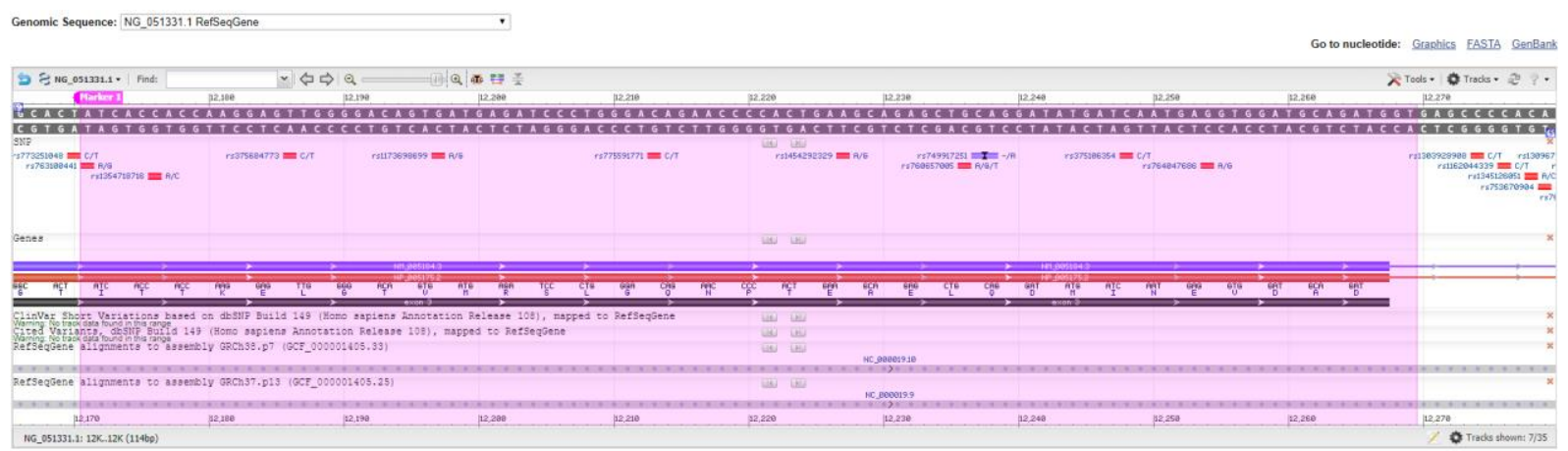

Figure 16. SNPs reported in the Pubmed database in the region matching the 3rd exon of the CALM3 gene. The Marker 1 region indicated in pink indicates the region that matches the SDHA gene. This region is between nucleotides 12,171 12,269 in the human genome 19. Chromosome, GRCh37.p13. Direction of arrows in the purple line The olive genome shows the direction of the 5'-3 Zeytin DNA sequence. The red regions indicated by the Rs numbers indicate the SNPs reported in the Pubmed database and the purple lines with longer lines indicate the deletion areas reported. The data obtained were investigated on 2018-03-27. 


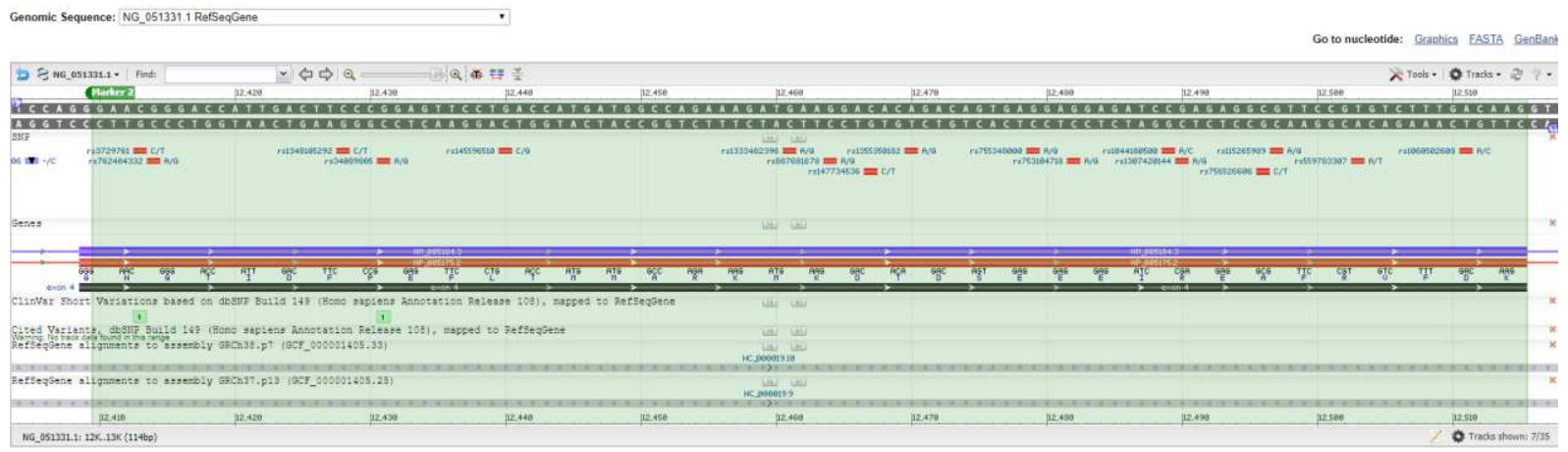

Figure 17. SNPs reported in the Pubmed database at the region matching the 4th exon of the CALM3 gene. This region is between nucleotides 12,410 - 12,515 in the Human genome 7. Chromosome, GRCh37.p13.

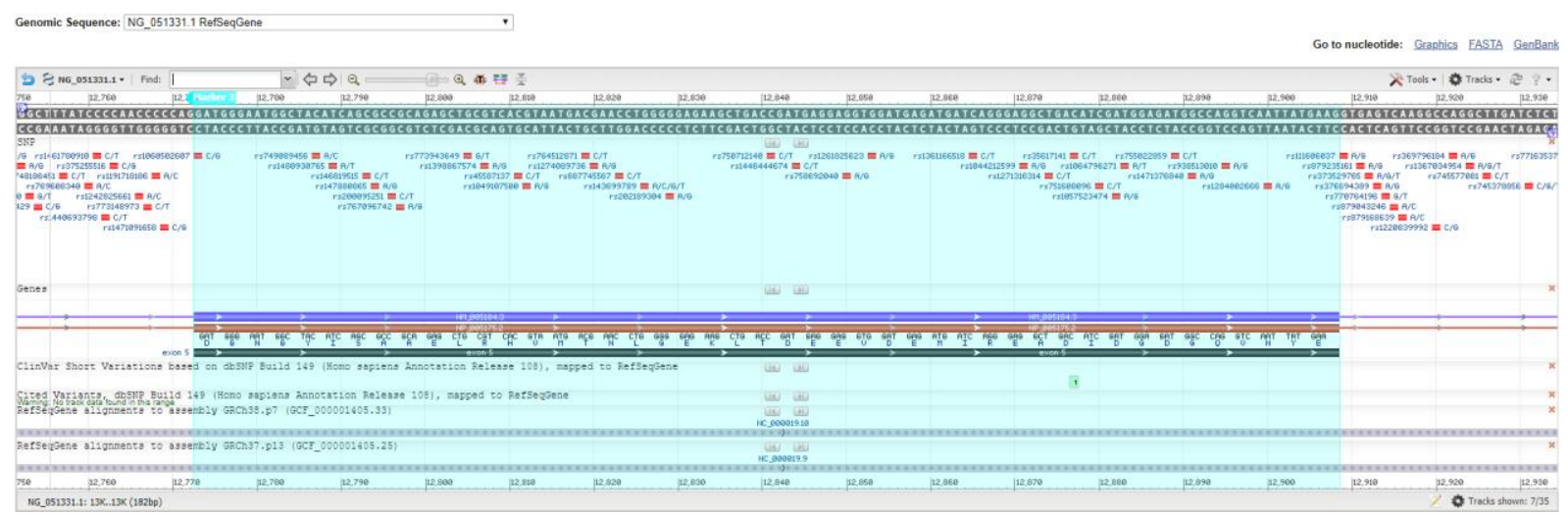

Figure 18. SNPs reported in Pubmed database in the region matching the 5th exon of the CALM3 gene.

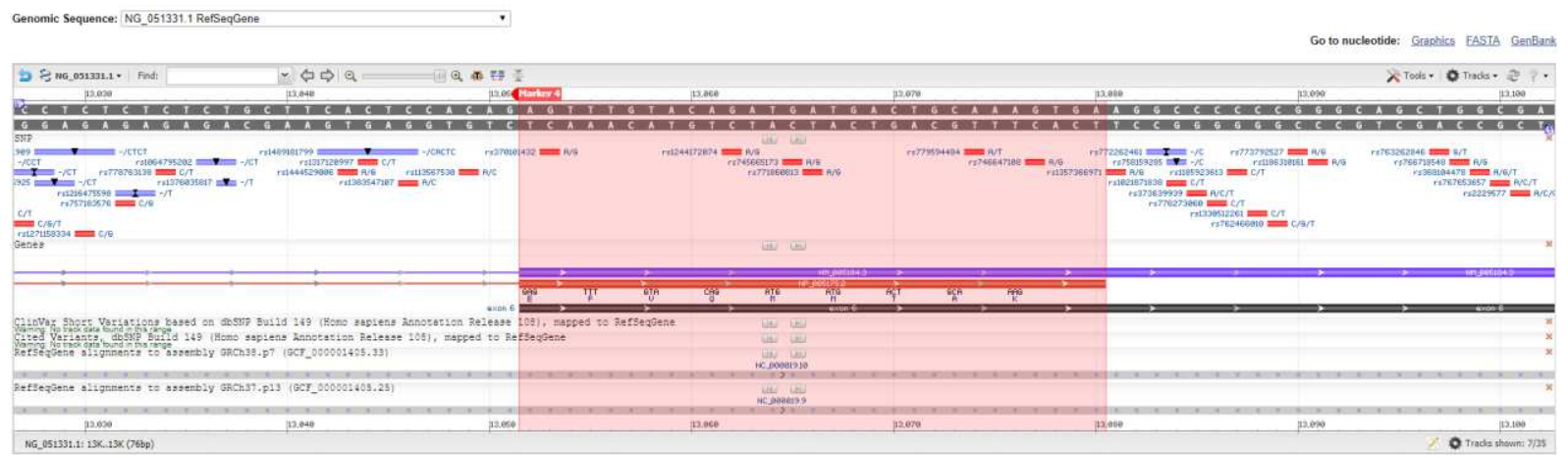

Figure 19. SNPs reported in the Pubmed database in the region matching the 6th exon of the CALM3 gene. This region is between the nucleotides 13,052 - 13,080 in the Human genome 7. Chromosome, GRCh37.p13.

- Three of the matching SNLs were pathologically demonstrated on Pubmed. (rs1060502608 [14], rs1064796271 [15], rs1555814427 [7] )

- $\quad$ The wild type form of most of the regions with SNP is found in the olive genome.

- $\quad$ There are many candidate regions for restriction enzymes in the 369 bp region where we found a match.

(Figure 20) 
Display: - NEB single cutter restriction enzymes

- Main non-overlapping, min. 100 aa ORFs

$\mathrm{GC}=48 \%, \mathrm{AT}=52 \%$

\begin{tabular}{l|l} 
- Cleavage code & Enzyme name code \\
Available from NEB \\
Has blunt end cut & Hasther supplier \\
II 5' extension & Not commercially available \\
I 3' extension & *: cleavage affected by CpG methylation \\
\#: cleavage affected by other methylation \\
(enz. name): ambiguous site
\end{tabular}

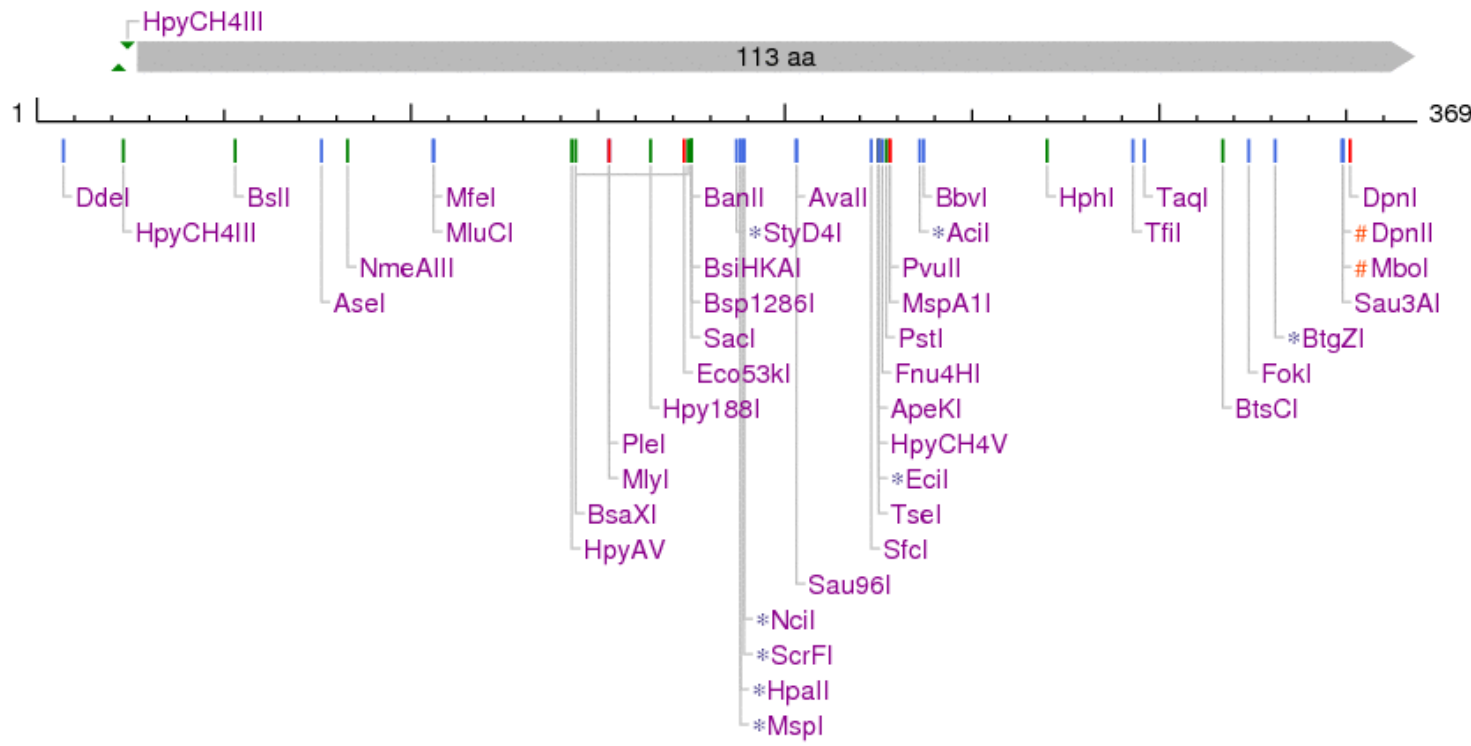

Figure 20. Restriction enzymes in the NEB database of the region matching the CALM 3 gene.

\section{CONCLUSION AND DISCUSSION}

As a result of our comparison between olive genome and human genome, we found matches in 67 genes. (Genes summary table). We focus our attention on cancer (BRAF, BRMS1L, SDHA) and cardiovascular system (CALM1, CALM3...) related genes We carried out a summary study on Pubmed about the functions of these genes and then compiled the reported mutation analyzes of these genes on the site 'Exac.browser' and searched for the presence of matching regions in the matching genes in olive. As can be expected, hundreds of mutations have been reported for each gene, but some of them have also led to very serious pathologies (Pathogenic Variants table). Human deletions or snps in the matching regions on the CALM3, SDHA, BRAF, BRMS1L and CALM1 gene are reported to cause pathological conditions. The wild type of these regions is found in the olive genome and there are many restriction enzymes capable of cutting these matching regions from the appropriate regions. We have seen that many restriction enzymes available today allow us to cut off our matching gene region from appropriate sites. Based on this, we concluded that the use of non-pathological sequencing from the genome of the olives that we consume can benefit individuals with mutations. Considering all this, we 
have come to the conclusion that GMO products may perhaps deprive living beings of this natural therapy by causing the genome that is treating us to be pathological, leading to even worse outcomes. In particular, can the olive genome be used for the repair of mutagenized genes as a guide DNA chain used in the cell repair mechanism? From another point of view, can genetic bioavailability also have an impact on explaining the idiopathic concept underlying many diseases that are still unclear? According to this hypothesis, can specific diets having common regions and genes involved in pathogenesis be included in our future treatment plans? With these matches, can we approach the relationship between diet and disease from a different perspective?

\section{REFERENCES}

[1] Nocella C, Cammisotto V, Fianchini L, D'Amico A, Novo M, Castellani V, et al. Extra Virgin Olive Oil and Cardiovascular Diseases: Benefits for Human Health. Endocr Metab Immune Disord Drug Targets. 2018;18:4-13. [2] De Bruno A, Romeo R, Fedele FL, Sicari A, Piscopo A, Poiana M. Antioxidant activity shown by olive pomace extracts. J Environ Sci Health B. 2018;53:526-33.

[3] Wongwarawipat T, Papageorgiou N, Bertsias D, Siasos G, Tousoulis D. Olive Oil-related Anti-inflammatory Effects on Atherosclerosis: Potential Clinical Implications. Endocr Metab Immune Disord Drug Targets. 2018;18:51-62.

[4] Boss A, Bishop KS, Marlow G, Barnett MP, Ferguson LR. Evidence to Support the Anti-Cancer Effect of Olive Leaf Extract and Future Directions. Nutrients. 2016;8.

[5] Nyegaard M, Overgaard MT, Sondergaard MT, Vranas M, Behr ER, Hildebrandt LL, et al. Mutations in calmodulin cause ventricular tachycardia and sudden cardiac death. Am J Hum Genet. 2012;91:703-12.

[6] Napolitano C, Priori SG, Bloise R. Catecholaminergic Polymorphic Ventricular Tachycardia. In: Adam MP, Ardinger HH, Pagon RA, Wallace SE, Bean LJH, Stephens K, et al., editors. GeneReviews((R)). Seattle (WA) 1993.

[7] Nykamp K, Anderson M, Powers M, Garcia J, Herrera B, Ho YY, et al. Sherloc: a comprehensive refinement of the ACMG-AMP variant classification criteria. Genet Med. 2017;19:1105-17.

[8] Erişim tarihi: 2018.03.27 https://www.ncbi.nlm.nih.gov/genome/?term=Olea+europaeaşlilşi

[9] Erişim tarihi: 2018.03.27 https://www.ncbi.nlm.nih.gov/gene/801

[10] Date of access: 2018.03.27 https://www.ncbi.nlm.nih.gov/clinvar/variation/39757/

[11] Date of access: 2018.12.22 https://sift.bii.a-star.edu.sg/sift-bin/SIFT_dbSNP_submit.pl

[12] Date of access: $2018.12 .22 \mathrm{https} / / / w w w . n c b i . n l m . n i h . g o v / s n p / r s 777 \overline{8} 73911$ \#clinical_significance

[13] Date of access: 2018.12.22 https://www.ncbi.nlm.nih.gov/clinvar/variation/486403/\#supporting-observations

[14] Date of access: 2018.12.22 https://www.ncbi.n/m.nih.gov/clinvar/RCV000475293.1/

[15] Date of access: 2018.12.22 https://www.ncbi.nlm.nih.gov/clinvar/RCV000484148.1/ 


\section{ATTACHMENTS}

Tablo 2. Matching regions between olive genome and human genome. The number of chromosomes of the olive genome and which gene overlaps in the human genome are shown in the table. The pairings examined on the genes show matches ranging from 29 to $1259 \mathrm{bp}$ with a similarity of $72 \%$ to $100 \%$.

\begin{tabular}{|c|c|c|c|c|}
\hline $\begin{array}{l}\text { Matching } \\
\text { Genes }\end{array}$ & $\begin{array}{l}\text { MATCHING } \\
\text { (BP-RATE) }\end{array}$ & $\begin{array}{l}\text { Matching Localization } \\
\text { (Bp / Chromosome) }\end{array}$ & $\begin{array}{l}\text { Number of SNPs and } \\
\text { Deletions }\end{array}$ & SEQUENCE ID \\
\hline CALM1 & $125 / 149(84 \%)$ & $\begin{array}{c}\text { 90,401,255 - 90,401,403 (149bp) } \\
\text { (GRCh38.p12) } \\
\text { human genome } 14 \mathrm{Chr} .\end{array}$ & 19 SNPs & NM_006888.4 \\
\hline CALM3 & $293 / 369(79 \%)$ & $\begin{array}{c}12,171-12,269 \\
12,410-12,515 \\
12,773-12,908 \\
13,052-13,080 \\
\text { (GRCh37.p13) } \\
\text { 19. Chromosome }\end{array}$ & 62 SNPs / 1 del. & NM_001329922.1 \\
\hline BRAF & $31 / 32(97 \%)$ & $\begin{array}{c}\text { 140,924,771-140,924,802 (32bp) } \\
\text { (GRCh38.p12) } \\
\text { 7. Chromosome }\end{array}$ & 9 SNPs / 9 del & NM_004333.5 \\
\hline SDHA & $77 / 92(84 \%)$ & $\begin{array}{l}\text { 225,880-222,971 (92bp) } \\
\text { (GRCh38.p12) } \\
\text { 7. Chrosome }\end{array}$ & 33 SNPs / 4 del. & NM_001330758.1 \\
\hline BRMS1L & $36 / 39(92 \%)$ & $\begin{array}{c}35,825,600-35,825,634 \text { (35bp) } \\
\text { (GRCh38.p12) } \\
\text { 14. Chromosome }\end{array}$ & 17 SNPs / 6 del. & XM_017021706.1 \\
\hline
\end{tabular}

Table 3.

\begin{tabular}{|c|c|c|c|}
\hline OLIVE GENOM & MATCHING GEN & MATCHING (BP-RATE) & SEQUENCE ID \\
\hline 1. CHROMOSOME & CALM3 & $293 / 369(79 \%)$ & NM_001329922.1 \\
\cline { 2 - 4 } & TUBB8P12 & $270 / 371(73 \%)$ & NM_001358689.1 \\
\cline { 2 - 4 } & HSP90AB1 & $67 / 80(84 \%)$ & NM_001271972.1 \\
\cline { 2 - 4 } & DDX27 & $31 / 31(100 \%)$ & NM_017895.7 \\
\cline { 2 - 4 } & STAM2 & $33 / 35(94 \%)$ & XR_001738586.1 \\
\cline { 2 - 4 } & MEF2C-AS1 & $29 / 29(100 \%)$ & NR_136222.1 \\
\hline \multirow{5}{*}{ 2. CHROMOSOME } & UBC & $887 / 1140(78 \%)$ & NM_021009.6 \\
\cline { 2 - 4 } & HSPA1L & $964 / 1323(73 \%)$ & NM_002155.4 \\
\cline { 2 - 4 } & HSPA6 & $901 / 1259(72 \%)$ & NM_001100.3 \\
\cline { 2 - 4 } & ACTA1 & $299 / 374(80 \%)$ & NM_001101.4 \\
\cline { 2 - 4 } & ACTB & $310 / 397(78 \%)$ & NM_001145442.1 \\
\cline { 2 - 4 } & POTEM & $288 / 372(77 \%)$ & \\
\cline { 2 - 4 } & & &
\end{tabular}




\begin{tabular}{|c|c|c|c|}
\hline & POTEF & $201 / 246(82 \%)$ & NM_001099771.2 \\
\hline & POTEI & 199/245(81\%) & XM_017004732.2 \\
\hline & POTEE & $193 / 236(82 \%)$ & XM_017004161.2 \\
\hline & POTEJ & 198/245(81\%) & NM_001277083.1 \\
\hline & LINC02250 & $30 / 30(100 \%)$ & XR_931996.2 \\
\hline & SIPA1L3 & $29 / 29(100 \%)$ & NM_015073.2 \\
\hline 3. CHROMOSOME & UBC & $300 / 368(82 \%)$ & NM_021009.6 \\
\hline & PPP1CC & $251 / 340(74 \%)$ & XM_011538505.3 \\
\hline & FUS & $36 / 39(92 \%)$ & XM_005255233.5 \\
\hline 4. CHROMOSOME & \multicolumn{3}{|c|}{ (NO MATCHED TRANSCRYPT FOUND) } \\
\hline 5. CHROMOSOME & $\mathrm{NISCH}$ & $28 / 28(100 \%)$ & NM_007184.3 \\
\hline \multirow[t]{3}{*}{ 6. CHROMOSOME } & LINC02250 & $100 \%$ & XR_931996.2 \\
\hline & LOC105376278 & $97 \%$ & XR_001746939.2 \\
\hline & NTN5 & $100 \%$ & XM_017026274.1 \\
\hline \multirow[t]{10}{*}{ 7. CHROMOSOME } & ACTA1 & $294 / 361(81 \%)$ & NM_001100.3 \\
\hline & ACTB & $296 / 370(80 \%)$ & NM_001101.4 \\
\hline & POTEF & 291/372(78\%) & \\
\hline & POTEM & $284 / 364(78 \%)$ & NM_001145442.1 \\
\hline & POTEI & $286 / 368(78 \%)$ & NM_001277406.1 \\
\hline & POTEE & $286 / 368(78 \%)$ & NM_001083538.1 \\
\hline & POTEJ & $284 / 368(77 \%)$ & NM_001277083.1 \\
\hline & TUBB8P12 & 299/398(75\%) & NM_001358689.1 \\
\hline & H3.Y & $78 / 94(83 \%)$ & NM_001355258.1 \\
\hline & LCN10 & $36 / 37(97 \%)$ & NM_001001712.2 \\
\hline \multirow[t]{3}{*}{ 8. CHROMOSOME } & ATP5F1B & $163 / 209(78 \%)$ & NM_001686.3 \\
\hline & BRMS1L & $36 / 39(92 \%)$ & XM_017021706.1 \\
\hline & ANKRD26 & $38 / 42(90 \%)$ & XM_017015929.1 \\
\hline 9. CHROMOSOME & \multicolumn{3}{|c|}{ (NO MATCHED TRANSCRYPT FOUND) } \\
\hline \multirow[t]{5}{*}{ 10. CHROMOSOME } & UBC & 727/921(79\%) & NM_021009.6 \\
\hline & ACTG1 & $292 / 375(78 \%)$ & NM_001199954.1 \\
\hline & LOC100130331 & $288 / 378(76 \%)$ & NR_027247.2 \\
\hline & SCO1 & $39 / 41(95 \%)$ & NM_004589.3 \\
\hline & LINC02250 & $29 / 29(100 \%)$ & XR_931996.2 \\
\hline 11. CHROMOSOME & MAGOH2P & $60 / 69(87 \%)$ & NR_049723.1 \\
\hline \multirow[t]{3}{*}{ 12. CHROMOSOME } & PSMC5 & 95/120(79\%) & XR_934508.2 \\
\hline & CALM1 & $86 \%$ & NM_006888.4 \\
\hline & MLLT3 & $100 \%$ & NM_004529.3 \\
\hline
\end{tabular}




\begin{tabular}{|c|c|c|c|}
\hline & LOC101927188 & $100 \%$ & NR_126040.1 \\
\hline & BHMG1 & $100 \%$ & NM_001310124.1 \\
\hline & FDFT1 & $100 \%$ & NM_001287750.1 \\
\hline \multirow[t]{7}{*}{ 13. CHROMOSOME } & SDHA & 77/92(84\%) & NM_001330758.1 \\
\hline & LOC220729 & $84 \%$ & NR_003266.2 \\
\hline & SDHAP2 & $82 \%$ & NR_003265.3 \\
\hline & SDHAP1 & $83 \%$ & NR_003264.2 \\
\hline & DIEXF & $100 \%$ & NM_014388.6 \\
\hline & TMEM9B & $100 \%$ & NM_020644.2 \\
\hline & CYTIP & $100 \%$ & NM_004288.4 \\
\hline \multirow[t]{13}{*}{ 14. CHROMOSOME } & АСТВ & $324 / 403(80 \%)$ & NM_001101.4 \\
\hline & \multirow[t]{2}{*}{ ACTA1 } & $308 / 380(81 \%)$ & \multirow[t]{2}{*}{ NM_001100.3 } \\
\hline & & 286/364(79\%) & \\
\hline & POTEM & 286/364(79\%) & NM_001145442.1 \\
\hline & POTEF & $313 / 405(77 \%)$ & NM_001099771.2 \\
\hline & POTEI & $78 \%$ & NM_001277406.1 \\
\hline & POTEE & $78 \%$ & NM_001083538.1 \\
\hline & POTEJ & $77 \%$ & NM_001277083.1 \\
\hline & H3.Y & $79 \%$ & NM_001355258.1 \\
\hline & LINC02250 & $100 \%$ & XR_931996.2 \\
\hline & WDR26 & $97 \%$ & NM_025160.6 \\
\hline & ASH1L & $100 \%$ & NM_018489.2 \\
\hline & LOC403312 & $100 \%$ & NM_001301851.1 \\
\hline \multirow[t]{9}{*}{ 15. CHROMOSOME } & \multirow[t]{2}{*}{ UBC } & 723/906(80\%) & \multirow[t]{2}{*}{ NM_021009.6 } \\
\hline & & 725/918(79\%) & \\
\hline & HIST1H3G & $307 / 385(80 \%)$ & NM_003534.2 \\
\hline & TUBA1C & 282/369(76\%) & NM_032704.4 \\
\hline & TUBA1B & $282 / 369(76 \%)$ & NM_006082.2 \\
\hline & UBB & $189 / 234(81 \%)$ & NM_018955.3 \\
\hline & PPP1CC & $250 / 340(74 \%)$ & NM_002710.3 \\
\hline & SIPA1L3 & 38/41(93\%) & NM_015073.2 \\
\hline & PLEKHG1 & $35 / 37(95 \%)$ & NM_001029884.2 \\
\hline 16. CHROMOSOME & \multicolumn{3}{|c|}{ (NO MATCHED TRANSCRYPT FOUND) } \\
\hline \multirow[t]{3}{*}{ 17. CHROMOSOME } & IGHMBP2 & 29/29(100\%) & XM_017017671.2 \\
\hline & BRAF & $31 / 32(97 \%)$ & NM_004333.5 \\
\hline & IGHMBP2 & 29/29(100\%) & NM_002180.2 \\
\hline
\end{tabular}




\begin{tabular}{|l|c|c|l|}
\hline \multirow{2}{*}{ 18. CHROMOSOME } & HIST1H3F & $84 \%$ & NM_021018.2 \\
\cline { 2 - 4 } & H3F3A & $81 \%$ & NM_002107.4 \\
\cline { 2 - 4 } & H3F3AP4 & $81 \%$ & NR_002315.1 \\
\hline \multirow{2}{*}{ 19. CHROMOSOME } & FDFT1 & $29 / 29(100 \%)$ & NM_001287750.1 \\
\cline { 2 - 4 } & SUPT20HL2 & $28 / 28(100 \%)$ & NM_001136233.2 \\
\hline \multirow{2}{*}{ 21. CHROMOSOME } & EEF1A1 & $361 / 450(80 \%)$ & NM_001402.5 \\
\cline { 2 - 4 } & TNFRSF10D & $28 / 28(100 \%)$ & NM_003840.4 \\
\hline \multirow{2}{*}{ 22. CHROMOSOME } & STK4 & $37 / 38(97 \%)$ & NM_006282.4 \\
\cline { 2 - 4 } & HOXB6 & $37 / 38(97 \%)$ & NM_018952.4 \\
\cline { 2 - 4 } & PSMC1 & $74 / 85(87 \%)$ & NM_002802.2 \\
\hline 23. CHROMOSOME & CALN1 & $29 / 29(100 \%)$ & NM_031468.3 \\
\hline \multirow{2}{*}{ EX CHROMOSOME } & CGN & $28 / 28(100 \%)$ & NM_020770.2 \\
\hline
\end{tabular}


Tablo 4 Possible pathogenic / pathogenic variations reported in matching regions.

\begin{tabular}{|c|c|c|c|c|c|c|c|}
\hline \multicolumn{2}{|c|}{ Pathogenic Variants } & \multirow[t]{2}{*}{ Position } & \multirow[t]{2}{*}{ Alleles } & \multirow[t]{2}{*}{ Clinical Significance } & \multirow[t]{2}{*}{$\begin{array}{l}\text { Gene : } \\
\text { Consequence }\end{array}$} & \multirow[t]{2}{*}{$\begin{array}{l}\text { Publication } \\
\text { (PMID) }\end{array}$} & \multirow[t]{2}{*}{$\begin{array}{l}\text { Olive } \\
\text { match }\end{array}$} \\
\hline Gene & SNPS & & & & & & \\
\hline CALM1 & rs 267607276 & $\begin{array}{c}\text { chr14:90401385 } \\
\text { (GRCh38.p12) }\end{array}$ & $\begin{array}{l}\text { NM_001363670.1:c.164A>G } \\
\text { NM_001363670.1:c.164A>T }\end{array}$ & Pathogenic & $\begin{array}{l}\text { Asn55Ser / } \\
\text { Asn55lle }\end{array}$ & 23040497 & $\mathrm{~A}$ \\
\hline \multirow[t]{12}{*}{ SDHA } & rs1560987595 & $\begin{array}{c}\text { chr5: } 225886 \\
\text { (GRCh38) }\end{array}$ & NM_004168.4:c.460G>A & No Data & Glu154Lys & No Data & G \\
\hline & rs749824479 & $\begin{array}{l}\text { chr5:225890 } \\
\text { (GRCh38.p12) }\end{array}$ & NM_004168.4:c.464A>G & $\begin{array}{c}\text { Uncertain } \\
\text { significance }\end{array}$ & Asn155Ser & No Data & A \\
\hline & rs569384870 & $\begin{array}{l}\text { chr5:225892 } \\
\text { (GRCh38.p12) }\end{array}$ & NM_004168.4:c.466T>C & $\begin{array}{l}\text { Uncertain } \\
\text { significance }\end{array}$ & Tyr156His & No Data & $T$ \\
\hline & rs1553997722 & $\begin{array}{c}\text { chr5: 225897 } \\
\text { (GRCh38) }\end{array}$ & NM_004168.4:c.471C>T & Uncertain significanc & $\begin{array}{c}\text { Synonymous } \\
\text { Gly109= }\end{array}$ & No Data & $\begin{array}{l}\text { G } \\
(-)\end{array}$ \\
\hline & rs759827541 & $\begin{array}{l}\text { chr5:225902 } \\
\text { (GRCh38.p12) }\end{array}$ & NM_004168.4:c.476C>A & Uncertain significanc & Pro159Gln & No Data & C \\
\hline & rs1060503711 & $\begin{array}{l}\text { chr5:225906 } \\
\text { (GRCh38.p12) }\end{array}$ & $\begin{array}{c}\text { NM_004168.4:C.480T>C / } \\
\text { T }>\mathrm{G}\end{array}$ & Uncertain significanc & $\begin{array}{l}\text { Phe160=/ } \\
\text { Phe160Leu }\end{array}$ & No Data & $\begin{array}{l}\text { C } \\
(-)\end{array}$ \\
\hline & rs 1060503712 & $\begin{array}{l}\text { chr5:225922 } \\
\text { (GRCh38.p12) }\end{array}$ & NM_004168.4:c.496G>A & Uncertain significanc & Gly166Arg & No Data & G \\
\hline & rs763578369 & $\begin{array}{c}\text { chr5: } 225925 \\
\text { (GRCh38) }\end{array}$ & NM_004168.4:c.499A>C & Uncertain significanc & Lys167Gln & No Data & A \\
\hline & rs1553997748 & $\begin{array}{c}\text { chr5: } 225929 \\
\text { (GRCh38) }\end{array}$ & NM_004168.4:c.503T>C & Uncertain significanc & Ile168Thr & No Data & $T$ \\
\hline & rs1553997754 & $\begin{array}{c}\text { chr5: } 225931 \\
\text { (GRCh38) }\end{array}$ & NM_004168.4:c.505T>C & Uncertain significanc & Tyr121His & No Data & $T$ \\
\hline & rs587782076 & $\begin{array}{c}\text { chr5: } 225938 \\
\text { (GRCh38) }\end{array}$ & NM_004168.4:c.512G>A & Uncertain significanc & Arg123His & No Data & G \\
\hline & rs1553997783 & $\begin{array}{c}\text { chr5: } 225956 \\
\text { (GRCh38) }\end{array}$ & NM_004168.4:c.530G>C & Uncertain significanc & Ser129Thr & No Data & $\mathrm{G}$ \\
\hline \multirow[t]{2}{*}{ CALM3 } & rs1060502608 & $\begin{array}{c}\text { chr19:46608584 } \\
\text { (GRCh38.p12) }\end{array}$ & NM_005184.4:c.281A>C & $\begin{array}{c}\text { Pathogenic } \\
\text { (Clinvar accesion) } \\
\text { RCV000475293.1 }\end{array}$ & Asp94Ala & No Data & $\mathrm{A}$ \\
\hline & rs1064796271 & $\begin{array}{c}\text { chr19:46608956 } \\
\text { (GRCh38.p12) }\end{array}$ & NM_005184.4:c.396T>A & $\begin{array}{c}\text { Pathogenic } \\
\text { (RCV000484148.1) }\end{array}$ & Asp132Glu & No Data & $\mathrm{T}$ \\
\hline
\end{tabular}

